\title{
A Comparison of Rice Straw and Whole-Crop Barley (Hordeum vulgare L.) Silage Supplements on Performance and Carcass Characteristics of Hanwoo (Bos taurus coreanae) Steers
}

\author{
Seung Hak Yang ${ }^{1,+}\left(\mathbb{D}\right.$, Won Ho Kim ${ }^{1,+}$, Suk-Nam Kang ${ }^{2}$, Ki Choon Choi ${ }^{1, *(1)}$ and Dahye Kim ${ }^{3, *}$ \\ 1 Grassland and Forage Division, National Institute of Animal Science, RDA, Seonghwan-Eup, \\ Cheonan-Si 330-801, Korea; y64h@korea.kr (S.H.Y.); kimwh@korea.kr (W.H.K.) \\ 2 Department of Animal Resources, Daegu University, Gyeongsan 712-714, Korea; sk-kang@daegu.ac.kr \\ 3 Faculty of Biotechnology, College of Applied Life Science, Jeju National University, Jeju 63243, Korea \\ * Correspondence: choiwh@korea.kr (K.C.C.); pioioiq10@gmail.com (D.K.); Tel.: +82-41-580-6752; \\ Fax: +82-41-580-6779 \\ + These authors contributed equally to this work.
}

Received: 28 September 2020; Accepted: 29 October 2020; Published: 31 October 2020

\begin{abstract}
This study aimed to analyze the effects of whole-crop barley silage (WCBS) and a high-concentrate diet combination to replace a rice straw/concentrate on growth performance, and meat quality of Hanwoo steers (HS). Twenty-four animals were allocated to two groups with a rice straw/concentrate control treatment (CON) and a WCBS/concentrate treatment group. The concentrate was offered to all animals based on live weight after a feeding trial of grass-based diets. Feed intake of WCBS was lower than the CON $(p<0.01)$ and intake of concentrate was lower in the WCBS group than the CON in all experimental phases $(p<0.01)$. WCBS increased backfat thickness (BFT) and slaughter weight $(p>0.05)$. The marbling score was slightly higher in the WCBS group $(p>0.05)$. WCBS-fed beef had higher crude fat, lower crude protein, and moisture contents. WCBS feeding increased the levels of alpha-linolenic acid $(p<0.01)$ and decreased arachidonic acid in meat $(p<0.02)$. Hanwoo steers fed WCBS/concentrate improved feed intake, carcass traits, meat price, palatability, and FA content compared to those fed rice straw/concentrate, suggesting that WCBS is a potential source for improving the growth performance and meat quality in Hanwoo steers with significant economic efficiency.
\end{abstract}

Keywords: hanwoo steers; whole crop silage; growth performance; carcass quality; fatty acids; economic efficiency

\section{Introduction}

Diet plays a primary role in altering the fatty acid (FA) composition in the body of pigs, sheep, and cattle [1]. Korean economic changes lead to increases in the demand for high-quality beef. Hanwoo is a major source of cattle meat with highly marbled beef production; it accounted for about $85 \%$ of slaughtered cattle in 2016 [2]. The demand for highly marbled beef has been raised; therefore, the use of grain-based diet when the fattening period has been increased in beef industries recently. Concentrate feed has excessive fermentable carbohydrate, which causes acidosis in beef cattle [3]. The replacement of plant-based materials in diet during the fattening period provides a significant impact on acidosis, as well as maintains the integrity and health of ruminal papillae and nutrient absorption. Nowadays, considerable quantities of concentrate are formulated with mixtures of grass or whole grain cereals, inter alia, to provide energy, protein, and essential nutrients to animals, and have 
been used to accomplish fattening of cattle in Korea, although the feed can cause excessive decreases in ruminal $\mathrm{pH}$ in the late fattening period [4]. Grain crops, such as maize, in agricultural markets for food and feed are increasingly being shifted to the energy market; therefore, estimates of international grain prices are increased by competition for biomass as bioenergy [5]. Therefore, the replacements for grain-based feeds with other type of sources, such as grass, need to be studied.

Grass and grass-based grains are essential for ruminants and are low-cost, natural feeds that provide high-quality roughage [6,7]. Furthermore, feeding grass results in an abundant lipid profile including PUFA, saturated FA (SFA), and conjugated linoleic acid (CLA) [8]. Beef quality, in particular, is largely related to the fat content and FA composition, and animal nutrition is a major factor influencing the FA composition of muscle [1]. High consumer demand in commercial areas requires Hanwoo (Bos taurus coreanae) steers to be fattened for slaughter in South Korea. In general, the skeletal muscle of beef is not only a protein source, but also contains appreciable quantities of polyunsaturated FA (PUFA), such as alpha linolenic acid (C18:3 n-3), linoleic acid (C18:2 n-6), and oleic acid (C18:1 n-9), which confer beneficial effects on consumer health [9]. Thus, meat production processes, to satisfy retailer and consumer demands, should attempt to include grass-enriched beef production systems, which must still meet quality expectations of consumers in terms of food quality [10]. However, it has been reported that fat from grass-finished beef may have a yellowish appearance from an elevated carotenoid content, indicating that grass-rich diets might produce negative effects on meat quality [8]. It has been shown that increasing the proportion of concentrate in forage-based diets for fattening ruminants can improve meat production efficiency [11]. In addition, the efficiency of utilization of absorbed nutrients for the synthesis of animal tissues or products is usually increased when concentrate is incorporated into a forage diet [12]. Furthermore, an appropriate combination of concentrate and forage in the diet optimizes the fattening of ruminants and results in a more rapid and efficient growth and heavier carcasses than by the intake of concentrate or forage alone [13]. Inclusion of fresh forage in the diet for lactating buffalo showed an increment of unsaturated fatty acids and reduced short-chain fatty acid percentage. In addition, sensory characteristics were also modified without affecting consumers; it concluded that the replacement of the green fodder in diet represents a low-cost feeding strategy to improve the health of the buffalo [14]. Serrapica et al. determined the effect of silage (fermented forage) and hay (wilted forage) on volatile compounds and sensory properties of traditional Caciocavallo cheese. Silage-based diet (SD) induced higher perceived intensities of several features including yellowness, overall flavor, lightness, tenderness and taste attributed salty, bitter and umami. In addition, SD had elevated amounts of ketones and fatty acids, whereas hay-based diet had terpene $\alpha$-pinene, which was not found in SD cheese [15].

Barley is a cereal derived from the annual grass Hordeum Vulgare. Its multipurpose grains take a top place in the farm for the feeding of livestock [16]. Barley could be used as the sole grain in diets for pigs, cattle, horses, sheep and goats. Conventionally, combinations of rice straw and concentrate have been feeding for Hanwoo cattle in South Korea [17]. Nowadays, it has become available on the market as silage of the whole crop barley. In general, lactic acid bacteria (LAB) have been used as inoculants for silage productions due to its higher efficiency of lactic acid production with lower contents of acetic acid and butyric acid. In addition, LAB prevents undesirable microbial growths at ensiled silages $[18,19]$. Lactobacillus plantarum is a lactic acid bacteria that is known to play a pivotal role in the nutritional improvement in silages by producing lactic acid and other metabolites during the ensiling process and is used as an additive for silage and haylage preparation [20]. Combinations of concentrate and L. plantarum that effectively mediate the application of barley silage in a conventional feeding system for steers in the long term have not been clarified. Therefore, the purpose of this study was to investigate the effects of a WCBS/concentrate feeding system compared with a rice straw/concentrate diet in terms of meat quantity and quality characteristics in Hanwoo steers. In addition, profitability strategy was determined between straw/concentrate and WCBS diet- fed Hanwoo steers. 


\section{Materials and Methods}

\subsection{WCBS Preparation}

Barley, cultivated at the National Institute of Animal Science (NIAS) of South Korea, was harvested at the ripening stage (Zadoks code 9) and was wilted under field conditions to obtain the moisture content of $70 \%$. The wilted forage was inoculated (by spraying method) with L. plantarum (Chung-Mi Bio Co., Anseong, Korea) at a rate of $100 \mathrm{~g} /$ ton of forage. Simultaneously, the samples were wrapped with 16-18 layers of polyethylene film by round bale silage wrapping machine (Bio325, Vicon, Soest, Germany) and stored for 90 days at room temperature. Rice straw was obtained from a beef cattle farm in Kangwon Province, Korea, and was chopped into small pieces (4-5 cm lengths) and fed to animals in the control (CON) group.

\subsection{Experimental Design and Animal Management}

The experimental program was designed according to the Hanwoo care and user guidelines of the National Institute of Animal Science (NIAS/section no. 100), which is approved by the Internal Community Act (ICA) [21]. A total of 24 Hanwoo steers with a mean bodyweight of $206.67 \pm 9.74 \mathrm{~kg}$ were obtained upon weaning (i.e., from 120 to 180 days of age). Animals were kept in individual cages at livestock farms located at Maam-myeon, Goseong-gun, and Gyeongsangnam-do, South Korea. Animals were individually penned and fed the experimental diets twice daily at 09:00 and 16:00 and the animals had free access to mineral blocks and water in troughs

A total of 24 steers were allocated to two groups (Control and WCBS treated groups), each consisting of 12 animals. The mean initial body weight (BW) of steers were $212.08 \mathrm{~kg}$ for the CON and $201.25 \mathrm{~kg}$ for the WCBS treatment group $(p>0.05)$. Growth performance, feed intake, slaughter characteristics, meat quality, and fatty acid (FA) compositions of experimental meat were determined. The feed conversion ratio was determined by the following method; FCR = Feed intake/bodyweight gain.

\subsection{Feeding System}

All animals were fed a concentrated diet appropriate to each experimental period based on Korean Feeding Standards for Hanwoo [21]. Thus, crude protein (CP) and total digestible nutrients (TDN) levels of the concentrate were formulated by a commercial feed company in accordance with growth stages of Hanwoo steers (Table 1). After roughage or silage feeding, the concentrate was offered at each feeding time at 09:00 and 16:00. The feed intake was measured daily at 08:00 and 15:00, i.e., prior to the next feeding. The present study determined four growing phases, i.e., day 137 (initial feeding), day 124 (first fattening, after initial period), day 184 (mid fattening), day 295 (finish fattening), and day 740 (final feeding). Randomly collected samples of concentrate, rice straw and barley silage were taken monthly to determine the chemical composition [22]. The chemical compositions of concentrate were determined and published previously [23].

Table 1. Feeding systems for steers in different experimental periods.

\begin{tabular}{|c|c|c|c|c|}
\hline Items & $\begin{array}{l}\text { Initial Feeding } \\
\text { Period }\end{array}$ & $\begin{array}{l}\text { First Fattening } \\
\text { Period }\end{array}$ & $\begin{array}{l}\text { Mid Fattening } \\
\text { Period }\end{array}$ & $\begin{array}{c}\text { Finish Fattening } \\
\text { Period }\end{array}$ \\
\hline $\begin{array}{c}\text { Concentrate } \\
\text { (\% of body weight) }\end{array}$ & 1.5 & 1.8 & 1.5 & ad libitum \\
\hline $\mathrm{CP}(\%)$ & 16 & 14 & 13 & 12 \\
\hline TDN (\%) & 70 & 72 & 73 & 75 \\
\hline $\begin{array}{c}\text { Forages } \\
\text { (Rice straw and WCBS) }\end{array}$ & ad libitum & ad libitum & ad libitum & ad libitum \\
\hline
\end{tabular}




\subsection{Chemical Composition Analysis}

Rice straw and barley silage dry matter content (DM) was determined by the freeze-drying method for $24 \mathrm{~h}$ [22] and in vitro dry matter digestibility (IVDMD) was determined using an ANKOM fiber analyzer (DAISY II, ANKOM Technology Corporation, Fairport, NY) [24,25]. Crude ash was obtained after combustion at $550{ }^{\circ} \mathrm{C}$ for $5 \mathrm{~h}$. Crude protein (CP), crude fat (CF), Neutral detergent (NDF), and Acid detergent (ADF) were determined $[22,26]$. The digestible energy values were calculated from total digestible nutrients (TDN) [21].

\subsection{Analysis of Carcass Traits}

To analyze carcass characteristics, samples of the muscle and the intermuscular adipose tissue surrounding the Musculus longissimus dorsi (M. longissimus dorsi) were collected after slaughter at a packing facility located at Eumseong in South Korea. Samples were stored at $4{ }^{\circ} \mathrm{C}$ for $48 \mathrm{~h}$ until further analysis. Intramuscular tissue of the M. longissimus dorsi was used to determine FA profiles. After $48 \mathrm{~h}$ post-slaughter chilling, a sample was removed from the left side of the carcass between the last rib and the first lumbar vertebra for evaluating back fat thickness (BFT) and rib-eye area (REA) traits. For the sensory evaluation, nine trained panelists recorded their preferences. After $30 \mathrm{~min}$ of blooming, the marbling score $(1=$ trace to $9=$ very abundant $)$, meat color $(1=$ very light cherry red to $7=$ very dark red), fat color $(1=$ white to $7=$ yellow $)$, texture $(1=$ very fine to $9=$ very coarse $)$, and maturity ( 1 = very young to $9=$ very old $)$ were assessed, based on the Animal Products Grading Service [2]. Briefly, BFT was determined by measurements taken perpendicular to the outside surface, at a point two-thirds of the length of the rib-eye, between the last rib and the first lumbar vertebra [16]. The REA was analyzed at the surface of the cut using a standard grid. Approximately $10 \mathrm{~g}$ of chopped muscle was mixed with $10 \mathrm{~mL}$ deionized water to measure the $\mathrm{pH}$ using a $\mathrm{pH}$ meter (F-12, Horiba, Japan). Cooking loss was measured according to the procedure described [27], i.e., the percentage weight loss of meat samples $(3 \times 3 \times 3 \mathrm{~cm})$ after cooking in a hot water bath until the internal temperature reached $70{ }^{\circ} \mathrm{C}$. Nine samples per treatment were cut into $1 \mathrm{~cm}^{2}$ cross-sections with the fiber direction, $1.5 \mathrm{~cm}$ in length to measure the shear force (SF). The SF was measured by the texture analyzer (TA-XT2i, Stable Microsystems Ltd., Godalming, UK) equipped with a $25 \mathrm{~kg}$ load cell, a Warner-Bratzler shear blade, and a test speed setting of $2.0 \mathrm{~mm} / \mathrm{s}$, and was reported as the maximum force $(\mathrm{kg})$.

\subsection{Fatty Acid Composition Analysis}

Lipids were extracted and homogenized with a chloroform/methanol solution using a homogenizer (PT-MR3100 Kinematica, Luzern, Switzerland) [28]. The chloroform was aspirated in the dry bath (Type $16500, \mathrm{USA}$ ) at $50^{\circ} \mathrm{C}$ using nitrogen gas. Methylation of the lipids was analyzed prior to injection into the gas chromatograph (HP 5890 II fixed with a G1513A auto-sampler; Hewlett Packard Co., Alto Palo, CA, USA). The FA content was determined using a silica capillary column $(100 \mathrm{~m} \times 0.25 \mathrm{~mm}$, i.d. $\times 0.20 \mu \mathrm{m}$ thickness, Supelco, SP) with ultrapure helium as a carrier gas (flow rate $=1.0 \mathrm{~mL} / \mathrm{min}$ ). The temperature for the injector and detector was $250{ }^{\circ} \mathrm{C}$. The initial temperature of the oven was $140{ }^{\circ} \mathrm{C}$, and was then increased to $220^{\circ} \mathrm{C}$ at a rate of $15^{\circ} \mathrm{C} / \mathrm{min}[29,30]$.

\subsection{Statistical Analysis}

The statistical analysis used the linear model procedures of SAS (SAS version 9.1 2002-2003, SAS Institute, Wake County, NC, USA) to report significant differences in the mean \pm standard errors of the means of replicates at nutrient compositions, BW, daily weight gain, feed intake, FCR, carcass traits, chemical composition, and fatty acid composition between two different feeding trials. The analysis measured mean differences at $5 \%$ and $1 \%$ levels between groups using Duncan's multiple range tests. 


\section{Results and Discussion}

In this study, the economic efficiency of replacing the rice straw with WCBS was determined in comparison with a control diet (using rice straw/concentrate), based on measurements of meat quality in Hanwoo steers. Table 2 presents the mean values for the nutrient composition of the WCBS and CON ratios. Higher content of CP (9.03 vs. 3.62, DM), ether extract (2.6 vs. $1.9 \mathrm{DM})$, in vitro dry matter digestibility (IVDMD; 63.02 vs. 51.63, DM), and total digestible nutrients (TDN; 61.85 vs. $47.03, \mathrm{DM}$ ) was noted in WCBS compared to control diet. Lower dry matter content (DM 40.75 vs. 90.01, DM), crude ash (CA, 8.64 vs. 32.41, DM), neutral detergent fiber (NDF, 53.62 vs. 80.02, DM), and acid detergent fiber (ADF, 34.72 vs. 53.14, DM) were recorded in the WCBS treatment than the control diet.

Table 2. Nutrient compositions of the control and whole-crop barley silage groups.

\begin{tabular}{lllll}
\hline Items (\%) & CON & WCBS & $\begin{array}{l}\text { SEM } \\
\text { (\%) }\end{array}$ & $\operatorname{Pr}^{\mathbf{1}} \mathbf{F}^{\mathbf{2}}$ \\
\hline Dry matter (DM), \% & 90.01 & 40.75 & 5.46 & 0.01 \\
Crude protein (CP) * $^{*}$ & 3.62 & 9.03 & 0.31 & 0.01 \\
Ether extract (EE) * & 1.90 & 2.60 & 0.90 & 0.05 \\
Crude ash (CA) * $_{\text {Neutral detergent fiber (NDF) }}^{*}$ & 32.41 & 8.64 & 0.42 & 0.01 \\
Acid detergent fiber (ADF) * & 80.02 & 53.62 & 1.35 & 0.01 \\
In vitro dry matter digestibility (IVDMD) $^{*}$ & 53.14 & 34.72 & 1.10 & 0.01 \\
Total digestible nutrient (TDN) * & 51.63 & 63.02 & 0.78 & 0.05 \\
\hline
\end{tabular}

CON: control-Rice straw; WCBS: whole-crop barley silage; ${ }^{1}$ Standard error of the mean for 12 steers. ${ }^{2}$ Significance level, ${ }^{*}$ DM basis.

Table 3 shows the mean values for growth performance and feed intake during the initial feeding, first-, mid-, and finish fattening period. Over the duration of the experimental periods, steers consumed $9975 \mathrm{~kg}$ of WCBS/concentrate (5775 kg WCBS and $4200 \mathrm{~kg}$ of concentrate) and $6836 \mathrm{~kg}$ of rice straw/concentrate (1736 of rice straw and $5100 \mathrm{~kg}$ concentrate). The CON group had a slightly higher initial mean body weight compared with WCBS, although the final mean body weights over all experimental periods were higher in the WCBS group compared to the CON $(p>0.05)$. The WCBS group had a higher daily body weight gain $(0.98 \mathrm{~kg})$ compared to the CON group $(0.87 \mathrm{~kg})$ in the initial feeding period $(p<0.05)$, whereas differences were not found in the fattening periods $(p>0.05)$. Nevertheless, intake of concentrate was lower in the WCBS group than in the CON in all experimental periods $(p<0.01)$. In the present study, it was noted that the total feed intake in DM basis was lower in WCBS than CON in all phases, although there was no significant difference in feed conversion ratio of WCBS group compared to CON. These results suggest that WCBS could provide an economically balanced concentrate replacer during all experimental periods, which is consistent with previous studies that show that high-quality forages improve performance and feed intake in steers $[8,31]$. 
Table 3. Effects of feeding whole-crop barley silage (WCBS)/concentrate on growth performance and feed intake for steers during different fattening periods.

\begin{tabular}{|c|c|c|c|c|c|c|c|c|c|c|c|c|c|c|c|c|c|c|c|c|}
\hline \multirow{2}{*}{ Items } & \multicolumn{4}{|c|}{ Initial Feeding Period } & \multicolumn{4}{|c|}{ First Fattening Period } & \multicolumn{4}{|c|}{ Mid Fattening Period } & \multicolumn{4}{|c|}{ Finish Fattening Period } & \multicolumn{4}{|c|}{ Whole Period } \\
\hline & $\mathrm{CON}^{1}$ & $T^{2}$ & SEM $^{3}$ & $\operatorname{Pr}^{4}$ & CON & $T$ & SEM & Pr & CON & $T$ & SEM & $\mathrm{Pr}$ & CON & $T$ & SEM & $\operatorname{Pr}$ & CON & $T$ & SEM & $\operatorname{Pr}$ \\
\hline Initial body weight $(\mathrm{kg})$ & 212.08 & 201.25 & 3.78 & 0.09 & 359.50 & 367.42 & 8.10 & 0.52 & 444.75 & 455.30 & 10.12 & 0.49 & 555.00 & 560.42 & 14.90 & 0.80 & 212.08 & 201.25 & 3.78 & 0.09 \\
\hline Final body weight $(\mathrm{kg})$ & 359.5 & 367.42 & 8.10 & 0.52 & 444.75 & 455.25 & 10.12 & 0.49 & 555.00 & 560.40 & 14.90 & 0.80 & 696.25 & 698.75 & 26.74 & 0.94 & 696.25 & 698.75 & 26.74 & 0.94 \\
\hline Daily weight gain $(\mathrm{kg} / \mathrm{d})^{5}$ & 0.87 & 0.98 & 0.03 & 0.05 & 0.71 & 0.73 & 0.02 & 0.52 & 0.63 & 0.60 & 0.04 & 0.06 & 0.88 & 0.86 & 0.09 & 0.88 & 0.77 & 0.80 & 0.04 & 0.71 \\
\hline Feed intake $(\mathrm{kg} / \mathrm{d})^{6}$ & 4.82 & 5.83 & 0.07 & 0.01 & 10.78 & 10.93 & 0.07 & 0.01 & 10.86 & 10.48 & 0.20 & 0.01 & 13.38 & 12.47 & 0.25 & 0.01 & 10.12 & 9.81 & 0.07 & 0.01 \\
\hline Concentrate $(\mathrm{kg} / \mathrm{d})^{7}$ & 2.68 & 2.34 & 0.02 & 0.01 & 6.60 & 4.58 & 0.11 & 0.01 & 8.25 & 6.62 & 0.22 & 0.01 & 11.85 & 10.44 & 0.27 & 0.01 & 7.34 & 6.05 & 0.07 & 0.01 \\
\hline Rice straw $(\mathrm{kg} / \mathrm{d})^{8}$ & 2.13 & - & 0.04 & & 4.19 & - & 0.05 & & 2.60 & - & 0.02 & & 1.52 & - & 0.02 & & 2.78 & - & 0.02 & \\
\hline WCB silage $(\mathrm{kg} / \mathrm{d})^{9}$ & - & 3.49 & 0.04 & & - & 6.35 & 0.02 & & - & 3.86 & 0.03 & & - & 2.03 & 0.01 & & - & 3.77 & 0.02 & \\
\hline FCR 10 & 5.54 & 5.95 & 0.26 & 0.64 & 15.19 & 14.97 & 0.60 & 0.66 & 17.23 & 17.47 & 1.31 & 0.74 & 15.20 & 14.50 & 1.39 & 0.82 & 13.15 & 12.27 & 0.64 & 0.74 \\
\hline$C P$ intake $(\mathrm{kg} / \mathrm{d})$ & 0.51 & 0.69 & 0.03 & 0.05 & 1.08 & 1.21 & 0.08 & 0.05 & 1.23 & 1.26 & 0.12 & 0.62 & 1.52 & 1.48 & 0.15 & 0.52 & 1.08 & 1.16 & 0.05 & 0.52 \\
\hline NDF intake $(\mathrm{kg} / \mathrm{d})$ & 2.41 & 2.49 & 0.03 & & 5.07 & 4.60 & 0.02 & & 4.10 & 3.69 & 0.03 & & 3.90 & 3.46 & 0.02 & & 3.87 & 3.56 & 0.02 & \\
\hline ME intake (M//day) & 47.06 & 42.79 & 0.07 & 0.01 & 109 & 82.68 & 0.11 & 0.01 & 118 & 96 & 0.25 & 0.01 & 155 & 135.2 & 0.29 & 0.01 & 107.1 & 89.16 & 0.09 & 0.01 \\
\hline
\end{tabular}

${ }^{1}$ CON: Rice straw and concentrate. ${ }^{2}$ T: WCBS and concentrate. ${ }^{3}$ Standard error of the mean. ${ }^{4}$ Probability levels. ${ }^{5}$ Total weight gain and daily weight gain calculated for each animal per day that it received the test diets. ${ }^{6-9}$ Feed intake, concentrate, and rice straw/WCBS calculated for each animal for each period that it received the test diets (kg/head/day, DM basis).

$\mathrm{FCR}$, feed conversion ratio ( $\mathrm{kg}$ feed $/ \mathrm{kg}$ gain), $\mathrm{CP} —$ crude protein, $\mathrm{NDF}$-Neutral detergent fiber, ME intake—-metabolizable. 
The effects of WCBS on carcass yield and quality traits were determined and the data are shown in Table 4. The WCBS supplement significantly increased back fat thickness (BFT, $p<0.05$ ). There are no significant changes, $(p<0.05)$ were reordered for slaughter weight and marbling score between control and experimental diet. However, the WCBS-based diet slightly increased the slaughter weight and marbling score more than the control diet. Besides, Rib-eye area (REA), dressing percentage, and quality traits (lean color, fat color, texture, maturity and quality grade) were almost too similar to control, but slight decreases were noted in the animal fed with WCBS. Previous studies involving different forage-to-concentrate ratios have demonstrated variable results with respect to carcass traits in fattening cattle. Higher subcutaneous and mesenteric adipose tissue weights in a high concentrate diet compared to a high roughage diet were due to the difference in the TDN intake among dietary treatments [32]. For carcass quality traits, the marbling score was slightly higher in the WCBS group $(p>0.05)$ and lean color in the WCBS group was a brighter red color $(p=0.08)$. The results of the present study based on a higher TDN intake in the WCBS group strongly agree with a previous study asserting that marbling tends to be positively associated with carcass weight and subcutaneous fat thickness [32,33].

Table 4. Effects of feeding whole-crop barley silage (WCBS)/concentrate on carcass yield and quality traits of Hanwoo steers.

\begin{tabular}{|c|c|c|c|c|}
\hline Items & $\mathrm{CON}^{1}$ & $\mathrm{~T}^{2}$ & SEM $^{3}$ & $\operatorname{Pr}^{4}$ \\
\hline Carcass weight $(\mathrm{kg})$ & 417.67 & 419.20 & 11.41 & 0.64 \\
\hline Back fat thickness (mm) & 9.92 & 13.50 & 1.10 & 0.05 \\
\hline Rib-eye area $\left(\mathrm{cm}^{2}\right)$ & 89.83 & 89.10 & 2.43 & 0.66 \\
\hline Dressing percent (\%) & 66.86 & 64.50 & 0.84 & 0.11 \\
\hline Quantity grade ${ }^{5}$ & 6.42 & 5.90 & 0.17 & 0.09 \\
\hline \multicolumn{5}{|l|}{ Quality traits } \\
\hline Marbling score 6 & 5.42 & 5.90 & 0.55 & 0.54 \\
\hline Lean color ${ }^{7}$ & 5.08 & 4.90 & 0.10 & 0.08 \\
\hline Fat color 8 & 2.92 & 2.80 & 0.10 & 0.51 \\
\hline Texture ${ }^{9}$ & 1.17 & 1.10 & 0.10 & 0.93 \\
\hline Mature ${ }^{10}$ & 2.08 & 1.90 & 0.11 & 0.17 \\
\hline Quality grade ${ }^{11}$ & 2.58 & 2.00 & 0.08 & 0.31 \\
\hline Total Price (廿) & $7,001,696$ & $7,387,892$ & 395,693 & 0.37 \\
\hline
\end{tabular}

${ }^{1}$ CON: Hanwoo steer fed rice straw + concentrate, ${ }^{2}$ T: Hanwoo steer fed WCBS + concentrate, ${ }^{3}$ Standard error of the mean, ${ }^{4}$ Probability levels, ${ }^{5}$ grade A (5 point) $\sim$ grade D $(2$ point $),{ }^{6}$ low fat $(1$ point $) \sim$ high fat $(5$ point $),{ }^{7}$ very light cherry red $(1$ point $) \sim$ very dark red $(7$ point $) .{ }^{8}$ white $(1$ point $) \sim$ yellow $(7$ point $),{ }^{9}$ very fine $(1$ point $) \sim$ very coarse (3 point), ${ }^{10}$ below 15 month old (1 point) $\sim$ from 15 to 26 month old ( 2 point), ${ }^{11}$ grade $1+(7$ point $) \sim$ grade 3 (1 point).

Fat color tended to be a creamier white compared to the $\mathrm{CON}(p>0.05)$. Barley sources in finishing diets produce lighter lean than maize grains, while fat color has been known to be determined by the concentration of carotenoids $[33,34]$. In addition, a previous study consistent with this result showed that up to $80 \%$ of carotenoids are destroyed in the ensiling process [8]. Consistent with the results of Murphy et al. [13], the current study indicates that a WCBS/concentrate combination was more feasible in improving carcass quality without the negative effect of carotenoids on fat color in beef cattle than by the intake of concentrate.

Thus, these studies suggest that WCBS can enhance the appearance for the consumer's choice of beef color, if they want a lighter meat, although texture, maturity, and quality grades were slightly higher in the CON $(p>0.05)$. The meat in the WCBS group had a lower moisture content and CP than that in the CON group, indicating that $\mathrm{CF}$ in the WCBS group was higher than that in the CON $(p<0.05$; Table 5$)$. These results concur with a previous study in which flavor desirability and flavor intensity increased with fat content but protein was not significantly different $(p>0.05)$, indicating that a higher fat content in WCBS steers tended to affect beef flavor in the sensory evaluation $[35,36]$. 
The results confirm that steers preferred eating combinations of WCBS/concentrate than the ration provided to the CON group

Table 5. Chemical composition and meat qualities of Hanwoo steer fed whole-crop barley silage (WCBS)/concentrate.

\begin{tabular}{lllll}
\hline & $\mathbf{C}^{\mathbf{1}}$ & $\mathbf{T}^{\mathbf{2}}$ & $\mathbf{S E M}^{\mathbf{3}}$ & $\mathbf{P r}^{\mathbf{4}}$ \\
\hline Chemical composition & & & & \\
Moisture (\%) & 65.57 & 61.72 & 1.08 & 0.04 \\
Crude fat (\%) & 12.51 & 17.72 & 1.42 & 0.03 \\
Crude protein (\%) & 21.02 & 19.66 & 0.38 & 0.04 \\
Ash (\%) & 0.89 & 0.90 & 0.01 & 0.85 \\
Meat qualities & & & & \\
Cooking loss (\%) & 26.09 & 24.98 & 0.76 & 0.33 \\
Shear force (kg) & 3.41 & 3.47 & 0.17 & 0.80 \\
Water holding capacity (\%) & 55.50 & 56.92 & 0.65 & 0.16 \\
pH & 5.67 & 5.65 & 0.01 & 0.32 \\
Surface Color & & & & 0.37 \\
CIE L * & 40.28 & 42.30 & 1.53 & 0.82 \\
a * & 22.86 & 23.05 & 0.56 & 0.57 \\
b * & 10.93 & 11.29 & 0.42 & \\
Sensory evaluation & & & & 0.44 \\
Juiciness & 4.92 & 5.10 & 0.31 & 0.45 \\
Tenderness & 4.90 & 5.04 & 0.24 & 0.61 \\
Flavor & 5.06 & 5.12 & 0.25 & \\
\hline
\end{tabular}

${ }^{1}$ CON: Hanwoo steer fed rice straw+ concentrate, ${ }^{2}$ T: Hanwoo steer fed WCB silage +concentrate. ${ }^{3}$ Standard error of the mean. ${ }^{4}$ Probability levels. ${ }^{*} \mathrm{CIE}$, Commision Internationale de Leclairage; L *: lighter, a * redness; $\mathrm{b}^{*}$ : yellowness.

Table 6 presents the relative proportions of FAs between the WCBS and CON groups. The C18:3 $\mathrm{n}-3$ concentrations increased in WCBS-fed steers compared to the CON $(p<0.01)$ and arachidonic acid $(\mathrm{C} 20: 4 \mathrm{n}-6)$ decreased $(p<0.02)$. A previous study reported that grass-based diets resulted in higher levels of omega-3 within the lipid fraction of the meat, while omega-6 levels were left unchanged. As the concentration of grain increases in the grass-based diet, the concentration of $n-3$ FAs decreases in a linear fashion [8]. Taking these results into consideration, it might be assumed that grass-finished beef consistently produces a higher concentration of n-3 FAs (without affecting n-6 FA content), resulting in a more favorable omega-6:omega-3 ratio. Furthermore, n-3 FAs reportedly interfere with the synthesis of C20:4 n-6 from C18:2 n-6 via several mechanisms, such as the displacement of FA of the n-6 series [37]. Unsaturated treatments with linseed and fish oil decrease the C20:4 n-6 concentration in beef cattle [38]. These results demonstrate that WCBS was effective in providing unsaturated FA sources for fattening cattle and has the potential to produce beef with an abundance of PUFA for consumers.

WCBS feeding tended to increase palmitoleic acid, stearic acid, oleic acid, vaccenic acid, eicosanoic acid, and MUFA, and decrease myristic acid, palmitic acid, linoleic acid, SFA, and PUFA compared to the CON diet $(p>0.05)$. Previous studies found that decreasing the concentrate: forage ratio might increase palmitoleic acid in meat due to the presence of a higher palmitoleic acid content in forage [39]. Our results agree with a previous study that showed that grass finished meat contains elevated concentrations of stearic acid (C18:0), the only SFA with a net neutral impact on serum cholesterol, although there were no significant differences between groups. Grain-fed beef consistently produces higher concentrations of MUFAs when compared to grass fed beef, which includes FAs such as oleic acid (C18:1 cis-9), the primary MUFA in beef [8]. Grass-fed beef reportedly has a higher concentration of trans vaccenic acid (C18:1 $\mathrm{t} 11)$, an important MUFA for the de novo synthesis of conjugated linoleic acid (CLA; $\mathrm{C} 18: 2 \mathrm{c}-9, \mathrm{t}-11)$, a potent anti-carcinogen that is synthesized within the body tissues [8]. The current study showed a similar trend to that of the previous study in terms of concentrate combinations with WCBS. 
Table 6. Fatty acid composition in Hanwoo steer meat fed whole-crop barley silage (WCBS)/concentrate (\%).

\begin{tabular}{lllll}
\hline & CON $^{\mathbf{1}}$ & $\mathbf{T}^{\mathbf{2}}$ & SEM $^{\mathbf{3}}$ & Pr $^{\mathbf{4}}$ \\
\hline C14:0 (myristic) & 3.77 & 3.71 & 0.24 & 0.86 \\
C16:0 (palmitic) & 28.70 & 27.79 & 0.74 & 0.41 \\
C16:1n-7 (palmitoleic) & 4.77 & 4.87 & 0.36 & 0.86 \\
C18:0 (stearic) & 12.30 & 12.41 & 0.65 & 0.91 \\
C18:1n-9 (oleic) & 47.41 & 48.56 & 1.33 & 0.55 \\
C18:1n-7 (vaccenic) & 0.46 & 0.47 & 0.23 & 0.41 \\
C18:2n-6 (linoleic) & 1.78 & 1.76 & 0.14 & 0.91 \\
C18:3n-6 ( $\gamma$-linolenic) & 0.10 & 0.10 & 0.01 & 0.63 \\
C18:3n-3 ( $\alpha$-linolenic) & 0.12 & 0.16 & 0.01 & 0.01 \\
C20:1n-9 (eicosanoic) & 0.38 & 0.42 & 0.03 & 0.38 \\
C20:4n-6 (arachidonic) & 0.20 & 0.15 & 0.01 & 0.02 \\
EFA & 0.42 & 0.42 & 0.02 & 0.87 \\
SFA & 44.78 & 43.80 & 1.36 & 0.62 \\
MUFA & 53.01 & 54.02 & 1.42 & 0.63 \\
PUFA & 2.21 & 1.78 & 0.35 & 0.41 \\
\hline
\end{tabular}

${ }^{1}$ C: Hanwoo steer fed rice straw + concentrate, ${ }^{2}$ T: Hanwoo steers fed WCBS + concentrate. ${ }^{3}$ Standard error of the mean. ${ }^{4}$ Significance levels. EFA = essential fatty acid. SFA = saturated fatty acid. USFA = Unsaturated fatty acid. MUFA = monounsaturated fatty acid. PUFA = polyunsaturated fatty acid.

Acidosis is related to the amount, frequency, and duration of grain feeding, due to the limit in buffering capacity in the rumen [40,41]. Grain feeding decreases the rumen bacterium Butyrivibrio fibrisolvens, the main rumen bacterium concerned with the biohydrogenation of linoleic acid and alpha linolenic acid, through a low ruminal $\mathrm{pH}[8,42]$. From a significant increase in alpha linolenic acid, it was suggested that WCBS could improve ruminal metabolic disorders, such as low $\mathrm{pH}$, by diminishing the usage of concentrate ( $\mathrm{pH}$ data not shown). Several studies have attempted to improve the levels of these FAs for the benefit of the consumer $[8,9,34,39]$. As reported in a previous study, omega-3 FAs in meat products have a beneficial role in neonatal development and human health [43]; the current study, which substituted a proportion of the concentrate diet with WCBS, exhibited beneficial FA enhancement properties. WCBS feeding increased concentrations of palmitoleic acid, stearic acid, oleic acid, and alpha linolenic acid in muscle and adipose tissues. These results strongly indicate that beef industries need to re-evaluate feeding management to improve the efficiencies of feed usage as well as meat quality traits, which may also improve sustainability and competitiveness with food sources for humans in the agricultural marketplace. The present study demonstrated that Hanwoo steers fed WCBS had a high fat content similar to grass-fed animals, as was also suggested in a previous study [44].

\section{Conclusions}

The current study proves that the Hanwoo steers fed a WCBS/concentrate ration had improved feed intake, carcass traits, meat price, palatability, and FA content compared to those fed rice straw/concentrate. It suggests that WCBS is a valuable source of feed for improving the growth performance and meat quality in Hanwoo steers with substantial profitability compared to rice straw/concentrate rations.

Author Contributions: Conceptualization, W.H.K. and K.C.C.; methodology and validation, K.C.C. and S.H.Y.; formal analysis, S.-N.K., S.H.Y. and D.H.K.; writing-original draft preparation S.H.Y., and D.K.; supervision and funding acquisition, K.C.C. and W.H.K. All authors have read and agreed to the published version of the manuscript.

Funding: This research was funded by Minister of Food, Agriculture, Forestry, and Fisheries: PJ006619.

Acknowledgments: We would like to thank the Minister of Food, Agriculture, Forestry, and Fisheries, for support to carry out this project under the grant no. PJ006619. We also extend our gratitude to NIAS, and RDA for their full support. Authors thank Woosung Feed Co., Korea for the feeding program during all phases. 
Conflicts of Interest: We certify that there is no conflict of interest with any financial organization regarding the material discussed in the manuscript.

\section{References}

1. Wood, J.D.; Enser, M.; Fisher, A.V.; Nute, G.R.; Sheard, P.R.; Richardson, R.I.; Hughes, S.I.; Whittington, F.M. Fat deposition, fatty acid composition and meat quality: A review. Meat Sci. 2008, 78, 343-358. [CrossRef] [PubMed]

2. Korean Institute for Animal Products Quality Evaluation (KAPE). Animal Grading Statistics; KAPE: Sejong, Korea, 2016.

3. Nagaraja, T.G.; Lechtenberg, K.F. Acidosis in feedlot cattle. Vet. Clin. Food Anim. 2007, 23, 333-350. [CrossRef] [PubMed]

4. Ogata, T.; Makino, H.; Ishizuka, N.; Iwamoto, E.; Masaki, T.; Ikuta, K.; Kim, Y.-H.; Sato, S. Long-term high-grain diet altered the ruminal $\mathrm{pH}$, fermentation, and composition and functions of the rumen bacterial community, leading to enhanced lactic acid production in Japanese Black beef cattle during fattening. PLoS ONE 2019, 14, e0225448. [CrossRef] [PubMed]

5. Huang, H.; von Lampe, M.; van Tongeren, F. Climate change and trade in agriculture. Food Policy 2011, 36, S9-S13. [CrossRef]

6. Mcgee, M. Recent developments in feeding beef cattle on grass silage-based diets. In Silage Production and Utilization, Proceedings of the XVth International Silage Conference, Madison, WI, USA, 27-29 July 2009; Park, R.S., Stronge, M.D., Eds.; Wageningen Academic Publishers: Wageningen, The Netherlands, 2009; pp. 51-64.

7. Al-Thuwaini, T.; Al-Shuhaib, M.B. The Effects of Grass-Based versus Grain-Based Feeding of Ruminants on the Human Hygienic Status, a Review. World 2019, 9, 174-180. [CrossRef]

8. Daley, C.A.; Abbott, A.; Doyle, P.S.; Nader, G.A.; Larson, S. A review of fatty acid profiles and antioxidant content in grass-fed and grain-fed beef. Nutr. J. 2010, 9, 10. [CrossRef]

9. Chung, K.Y.; Lee, S.H.; Cho, S.H.; Kwon, E.G.; Lee, J.H. Current situation and future prospects for beef production in South Korea-A review. Asian-Australas J. Anim. Sci. 2018, 31, 951-960. [CrossRef] [PubMed]

10. Gotoh, T.; Nishimura, T.; Kuchida, K.; Mannen, H. The Japanese Wagyu beef industry: Current situation and future prospects-A review. Asian-Australas. J. Anim. Sci. 2018, 31, 933-950. [CrossRef]

11. Moody, M.L.; Zanton, G.I.; Daubert, J.M.; Heinrichs, A.J. Nutrient Utilization of Differing Forage-to-Concentrate Ratios by Growing Holstein Heifers1. J. Dairy Sci. 2007, 90, 5580-5586. [CrossRef]

12. Niderkorn, V.; Baumont, R. Associative effects between forages on feed intake and digestion in ruminants. Anim. Int. J. Anim. Biosci. 2009, 3, 951-960. [CrossRef] [PubMed]

13. Murphy, T.A.; Loerch, S.C.; McClure, K.E.; Solomon, M.B. Effects of grain or pasture finishing systems on carcass composition and tissue accretion rates of lambs. J. Anim. Sci. 1994, 72, 3138-3144. [CrossRef]

14. Uzun, P.; Masucci, F.; Serrapica, F.; Napolitano, F.; Braghieri, A.; Romano, R.; Manzo, N.; Esposito, G.; Di Francia, A. The inclusion of fresh forage in the lactating buffalo diet affects fatty acid and sensory profile of mozzarella cheese. J. Dairy Sci. 2018, 101, 6752-6761. [CrossRef]

15. Serrapica, F.; Uzun, P.; Masucci, F.; Napolitano, F.; Braghieri, A.; Genovese, A.; Sacchi, R.; Romano, R.; Barone, C.M.A.; Di Francia, A. Hay or silage? How the forage preservation method changes the volatile compounds and sensory properties of Caciocavallo cheese. J. Dairy Sci. 2020, 103, 1391-1403. [CrossRef] [PubMed]

16. Nikkhah, A. Barley grain for ruminants: A global treasure or tragedy. J. Anim. Sci. Biotechnol. 2012, 3, 22. [CrossRef] [PubMed]

17. Kim, D.; Amanullah, S.M.; Lee, H.; Joo, Y.H.; Han, O.; Adesogan, A.; Kim, S.C. Effects of Different Cutting Height on Nutritional Quality of Whole Crop Barley Silage and Feed Value on Hanwoo Heifers. Asian-Australas J. Anim. Sci. 2016, 29, 1265-1272. [CrossRef] [PubMed]

18. Nascimento Agarussi, M.C.; Gomes Pereira, O.; Paula, R.A.d.; Silva, V.P.d.; Santos Roseira, J.P.; Fonseca e Silva, F. Novel lactic acid bacteria strains as inoculants on alfalfa silage fermentation. Sci. Rep. 2019, 9, 8007. [CrossRef]

19. Soundharrajan, I.; Kuppusamy, P.; Park, H.; Kim, J.; Kim, W.; Jung, J.; Choi, K. Lactic Acid Bacteria Mixture as Inoculants on Low Moisture Italian Ryegrass Silage Fermentation. J. Korean Soc. Grassl. Forage Sci. 2019, 39, 127-131. [CrossRef] 
20. Kim, D.H.; Amanullah, S.M.; Lee, H.J.; Joo, Y.H.; Kim, S.C. Effect of Microbial and Chemical Combo Additives on Nutritive Value and Fermentation Characteristic of Whole Crop Barley Silage. Asian-Australas. J. Anim. Sci. 2015, 28, 1274-1280. [CrossRef]

21. ICA. Committee on Korean Feeding Standard for Hanwoo, National Research Council. Nutrient Requirements of Hanwoo, 3rd ed.; National Institute of Animal Science, R.D.A.: Jeonju, Korea, 2017.

22. AOAC. Official Methods of Analysis Association of Official Analytical Chemists; AOAC: Washington, DC, USA, 1995.

23. Kim, W.H.; Kang, S.-N.; Arasu, M.V.; Chu, G.-M.; Kim, D.H.; Park, J.-H.; Oh, Y.K.; Choi, K.C. Profile of Hanwoo Steer Carcass Characteristics, Meat Quality and Fatty Acid Composition after Feeding Italian Ryegrass Silage. Korean J. Food Sci. Anim. Resour. 2015, 35, 299-306. [CrossRef]

24. Holden, L.A. Comparison of Methods of In Vitro Dry Matter Digestibility for Ten Feeds. J. Dairy Sci. 1999, 82, 1791-1794. [CrossRef]

25. Melaku, S.; Aregawi, T.; Nigatu, L. Chemical composition, in vitro dry matter digestibility and in sacco degradability of selected browse species used as animal feeds under semi-arid conditions in Northern Ethiopia. Agrofor. Syst. 2010, 80, 173-184. [CrossRef]

26. Serrapica, F.; Masucci, F.; Raffrenato, E.; Sannino, M.; Vastolo, A.; Barone, C.; Di Francia, A. High Fiber Cakes from Mediterranean Multipurpose Oilseeds as Protein Sources for Ruminants. Animals 2019, 9, 918. [CrossRef] [PubMed]

27. Oillic, S.; Lemoine, E.; Gros, J.B.; Kondjoyan, A. Kinetic analysis of cooking losses from beef and other animal muscles heated in a water bath-effect of sample dimensions and prior freezing and ageing. Meat Sci. 2011, 88, 338-346. [CrossRef] [PubMed]

28. De Paola, E.L.; Montevecchi, G.; Masino, F.; Antonelli, A.; Lo Fiego, D.P. Single step extraction and derivatization of intramuscular lipids for fatty acid Ultra Fast GC analysis: Application on pig thigh. J. Food Sci. Technol. 2017, 54, 601-610. [CrossRef]

29. Lepage, G.; Roy, C.C. Direct transesterification of all classes of lipids in a one-step reaction. J. Lipid Res. 1986, 27, 114-120.

30. Estévez, M.; Morcuende, D.; Ventanas, S.; Cava, R. Analysis of Volatiles in Meat from Iberian Pigs and Lean Pigs after Refrigeration and Cooking by Using SPME-GC-MS. J. Agric. Food Chem. 2003, 51, 3429-3435. [CrossRef] [PubMed]

31. Christensen, D.A.; Owen, B.D.; Steacy, G.; Mtimuni, J.P.; Crowle, W.L. Nutritive value of whole crop silage made from seven cereal cultivars. Can. J. Anim. Sci. 1977, 57, 537-542. [CrossRef]

32. Yamada, T.; Nakanishi, N. Effects of the roughage/concentrate ratio on the expression of angiogenic growth factors in adipose tissue of fattening Wagyu steers. Meat Sci. 2012, 90, 807-813. [CrossRef]

33. Bown, M.D.; Muir, P.D.; Thomson, B.C. Dairy and beef breed effects on beef yield, beef quality and profitability: A review. N. Z. J. Agric. Res. 2016, 59, 174-184. [CrossRef]

34. Oliveros, M.C.R.; Park, K.M.; Kwon, E.G.; Choi, N.; Chang, J.S.; Hwang, I.H. Carcass Traits and the Quality of Meat from Cattle Finished on Diets Containing Barley. Asian-Australas J. Anim. Sci. 2009, 22, 1594-1608. [CrossRef]

35. Owens, F.; Gardner, B.A. Ruminant nutrition and meat quality. Proc. Annu. Recipr. Meat Conf. 1999, 52, 25-36.

36. Hwang, Y.-H.; Joo, S.-T. Fatty Acid Profiles, Meat Quality, and Sensory Palatability of Grain-fed and Grass-fed Beef from Hanwoo, American, and Australian Crossbred Cattle. Korean J. Food Sci. Anim. Resour. 2017, 37, 153-161. [CrossRef] [PubMed]

37. Ratnayake, W.M.N.; Olsson, B.; Ackman, R.G. Novel branched-chain fatty acids in certain fish oils. Lipids 1989, 24, 630-637. [CrossRef] [PubMed]

38. Scollan, N.D.; Choi, N.J.; Kurt, E.; Fisher, A.V.; Enser, M.; Wood, J.D. Manipulating the fatty acid composition of muscle and adipose tissue in beef cattle. Br. J. Nutr. 2001, 85, 115-124. [CrossRef]

39. French, P.; Stanton, C.; Lawless, F.; O’Riordan, E.; Monahan, F.; Caffrey, P.; Moloney, A.P. Fatty acid composition, including conjugated linoleic acid, of intramuscular fat from steers offered grazed grass, grass silage, or concentrate-based diets. J. Anim. Sci. 2000, 78, 2849-2855. [CrossRef]

40. Nagaraja, T.G.; Titgemeyer, E.C. Ruminal acidosis in beef cattle: The current microbiological and nutritional outlook. J. Dairy Sci. 2007, 90 (Suppl. 1), E17-E38. [CrossRef] 
41. Lopez, E.; Itzá-Ortiz, M.; Peraza-Mercado, G.; Chávez, J. Ruminal acidosis: Strategies for its control. Austral. J. Vet. Sci. 2017, 49, 139-148. [CrossRef]

42. Jeyanathan, J.; Escobar, M.; Wallace, R.J.; Fievez, V.; Vlaeminck, B. Biohydrogenation of 22:6n-3 by Butyrivibrio proteoclasticus P18. BMC Microbiol. 2016, 16, 104. [CrossRef]

43. Simopoulos, A.P. Essential fatty acids in health and chronic disease. Am. J. Clin. Nutr. 1999, 70, 560s-569s. [CrossRef]

44. Warren, H.; Enser, M.; Richardson, I.; Nute, G.; Wood, J.; Dhanoa, M.; Scollan, N. Effect of diet, breed and age at slaughter on the fatty acid composition of total lipid in beef longissimus muscle. In Proceedings of the 7th British Grassland Society (BGS) Research Conference, Aberystwyth, UK, 1-3 September 2003; British Grassland Society: Kenilworth, UK, 2015.

Publisher's Note: MDPI stays neutral with regard to jurisdictional claims in published maps and institutional affiliations.

(C) 2020 by the authors. Licensee MDPI, Basel, Switzerland. This article is an open access article distributed under the terms and conditions of the Creative Commons Attribution (CC BY) license (http://creativecommons.org/licenses/by/4.0/). 